\title{
Man as creator of Behavioural Competitiveness of Enterprises - conceptual model
}

\author{
Michat AdAM LeŚNIEWSKI ${ }^{1}$ \\ Jan Kochanowski University in Kielce, Institute of Management
}

Our knowledge begins in what we feel.

Leonardo da Vinci

\begin{abstract}
Man is the primary resource of every organization, he gives rise to the resources at the disposal of the organization (enterprise) and is the source of creating competitiveness, including the behavioural competitiveness whose analysis is the subject of this study.

It is assumed that: Man is the source of behavioural competitiveness (thesis 1), Man is a behavioural being, which confirms the concept of Behavioural Man (thesis 2) and that Competitive Man and Behavioural Man with factor-dependent relations and behaviours contribute to the generation of the model of Behavioural Competitiveness (thesis 3 ). The theses presented is examined through the interpretation of the literature of the subject.
\end{abstract}

Paper type: conceptual article

Key words: Behavioural Man, Competitive Man, Model of Behavioural Competitiveness of enterprises, Man as Creator.

\section{Introduction}

Every organization thinking about its future must base its development on man as the primary source of resources that give rise to other resources (man as a source of resources). Man in an organization with a positive attitude is seen as the creator of all the changes, initiatives and other pro-development activities (Man

${ }^{1}$ michaladam.lesniewski@wp.pl, konkurencyjnosc.com.pl 
Creator - Creative Man). Man as a creating individual should be perceived as quality that will result in different possibilities that will bring the organization closer to success (Jedynak, 2010, pp. 5-136). Man should be treated as an intellectual who enables active shaping of development and vision of development of organization in the future (Kozina, 2014, pp. 69-81). Man, in addition to being the primary resource of an organization, must contribute to stimulating own actions, among others by being, for example, Behavioural Man and Competitive Man. These two concepts of man constitute a proprietary view of the discussed scientific problem and the problem of economic practice. Behaviour and competitiveness (behavioural competitiveness - competitiveness of behaviours) complement each other and provide a different perspective not only of man, but also the whole organization (Czakon, 2017, pp. 143-160).

The aim of the study is to present the concept of behavioural competitiveness of enterprises. The study assumes that man is a source of behavioural competitiveness (1), man is a behavioural being, which confirms the concept of Behavioural Man, (2) and that the concept of Competitive Man and Behavioural Man with relations and factor-dependent behaviours contributes to the generation of Behavioural Competitiveness (3). The presented theses have been developed based on the interpretation of the literature of the subject. For this purpose, the following has been used: logical reasoning (in other words: logical thinking) and perception, allowing for combining different aspects into one compact whole and giving a picture of the known reality surrounding a given author. This method enables presentation of the point of view of the author of the study. This method uses, among others: theoretical experience, practical experience and theoretical-practical experience (combining theory and practice). This method is commonly used in the world of science and business practice, constituting the basis of the reactive or proactive human activity aiming at gaining the knowledge about the surrounding world. In logical reasoning - from the perspective of the author of the study - this method can be called the queen of methods (Leśniewski, 2017, p. 78).

\section{Man as creator of organization}

People are the basis of every organization regardless of the existing systems: political, economic or relating to the organization management (Oczkowska, 2014, pp. 5-182). One can say that man is the creator of the organization (Leśniewski, 2015, pp. 5-258). Man gives it a beginning and an end. The focus of science and business practice on soft factors (Leśniewski, 2015, pp. 5-258) proved to be more important in managing organizations (including managing human resources and contributing to the success of the organization) than classical factors such as: machines, devices, equipment or buildings. Science and business practice prove that 
organizations will not succeed if their employees are not engaged in their activities in a voluntary and unforced manner. Organizations will also not succeed if their employees are not motivated intrinsically and do not show initiative (Juchnowicz, 2012, pp. 5-184; Juchnowicz, 2009, pp. 5-536; Wojtczuk-Turek, 2008, pp. 471-483). Organizations should strive to make employees identify with it, share its goals and be assimilated with the organization (Budzanowska-Drzewiecka, Marcinkowski, \& Motyl-Adamczyk, 2016, pp. 5-168). This effect will only be achieved if a system of values and a system of needs is the same for both the employee and organization.

Crozier (1993) shows the differences in the approach to an employee as part of scientific management. In his view, scientific management of the company in its extreme variant eliminates all the decisions of individuals; scientific economic management reduced man to a quantitative category of demand. In both cases, investing is understood as expenditures on the material sphere. Even education is treated here as a quantitative investment. New thinking is based on completely different priorities. It is symbolized by the prevalence of cycle "modern technology - services" over cycle "mass production - mass consumption" (Crozier, 1993, pp. 26-27). It is indispensable in modern times to mobilize human resources in order to create and realize competitiveness, innovation and entrepreneurship, which are necessary for functioning in a market economy. The importance of man in the organization is also emphasized by the authors who treat organizations as social creations or a specific type of social relations system (Barnard, 1938; Etzioni, 1964, pp. 5-20; Hauswald, 1935; Katz \& Kahn, 1979, pp. 5-780). However, human activity strongly emphasizes concepts related to the way people act. They place people at the centre of organizational activities, which causes the organization to be treated as the creation of social relations. This approach proves that people are the essential element of every organization and it is these people, along with their systems of values, goals, skills and motivation, who contribute to achieving its goals and, consequently, to the success of the whole. Success, to be fully achieved, is possible only in the situation where employees of the organization pursue their goals together with the goals of the organization (purposeful cohesion). There should be a bi-directional relationship between the organization and employees, that is, the organization should contribute to the success of people (organization - people) and people should contribute to the success of the organization (people - organization). The success of the organization should be complemented by treating man (employee) as the subject of action. Man as a subject can better fulfil his duties, make independent decisions and create the surrounding reality. And this significantly affects the success of the entire organization. Man, as a rational being, can think, anticipate events, learn about reality through concepts, distinguish between instinctive, emotional, sensible and thoughtful behaviours (Szulich, 2004, p. 36). $\mathrm{He}$ is responsible for his actions, which distinguishes him from objects and animals. This difference is also emphasized by the language, because word "someone" is used only in relation to the person while word "something" is used in relation to 
other categories of animated nature and the material world. Man acts as a subject only when he actively participates in action, which is manifested in the very fact of setting a goal. He subordinated the sequence of events and activities to achieving the intended result. Subjectivity, which consists of initiating and developing one's own standards and values, is a specific type of regulation of human relations with the environment. It is the human being who regulates these relations instead of being the place where the regulatory processes are carried out; based on own values and standards, man formulates own goal or direction of activity which can also be adapted from the external environment and then takes specific actions for its implementation. Finally, an assessment of changes in own behaviour is made. The control of performed activities is also necessary. The entity exercising control consciously and to the extent chosen by them is the subject (Sułkowski, Rozkwitalska, \& Magala, 2017, pp. 155-171).

\section{Behavioural Man}

Man as a rational and intelligent being gives all the grounds for being the creator of the organization. It is difficult to create a holistic image that would cover every aspect of a human being and would be a kind of compendium of knowledge about man. Therefore, presenting man through a given prism is an easier task that can help detail the human activity in the organization.

The author's concept presented in the study is to show Man as a behavioural being and Behavioural Man (Marek, 2011, pp. 78-91), which should be preceded by the presentation of behaviourism. This is the direction in psychology and the method of practising it. In philosophy, however, it is a view of the nature of the mind and its relation with the body (Szubaka, 2004). Watson, who in 1913 published manifesto Psychology as seen by the behaviourist (Watson, 1990, pp. 5-442), is the creator of behaviourism. His manifesto presented his concept of psychology. It rejected the analysis of consciousness and introspection as a subjective and unscientific method. Instead, it focuses on the conditioning behaviours and factors, that is, on "situations." This manifesto is treated as the birth of behaviourism. According to him, the behaviour takes the form of stimulus-response (S-R), i.e. the correct relationships between -stimuli and body reactions. Watson (1990) believes that each new-born can be raised to be a human with any character traits, regardless of genes. In this way he refers to the philosophy of Aristotle (later popularized by Lock), in which man is born as a tabula rasa (a blank page), which is gradually filled with content throughout life and with experience. Behaviourism is derived from experimental psychology. His main goal is, above all, description, prediction and explanation of the behaviour of organisms (Marek, 2011, pp. 78-91). This manifesto is a kind of pamphlet, a protest against psychophysiology, the concept of 
consciousness recognizing it as "artificial." He opposed the psychophysical parallelism, rejecting one of the two "building" substances of man, that is, the immaterial (spiritual) one. He also departed from the instructive method, regarding it as subjective and created the new truly scientific and empirical psychology program. According to Watson, a psychologist should use only an objective method of research, as naturalists do. Through systematic observation and introduction of generalizations based on experiments and observations, hypotheses should be formulated and verified in relation to the laws and principles governing human behaviour. The most well-known representatives of behaviourism are: Pawłow (researcher of reactive conditioning), Thorndike (instrumental conditioning), Watson (reactive conditioning), Hull (the creator of the theory integrating reactive conditioning and instrumental conditioning) and Skinner (operant conditioning). Behaviourism focuses on the external environment and human reaction (stimulus - reaction). In further analysis of behaviourism, it can be stated that the environment in which a man is located is the source of stimuli to which a person reacts and adopts a specific behaviour (stimulus - reaction - behaviour). A critical look at behaviourism is that it focuses on the external environment of man, while this behaviour is not the only thing that surrounds man since there is also the inside of a person (psychological side). Therefore, behaviourism should be supplemented (developed) with the psychological side of a human being. Summing up, behaviourism can be presented considering the psychological side of man in the form of an external stimulus and an internal stimulus - reaction - behaviour. In the case of stimuli, the order is irrelevant because a person can be stimulated to act either through an external-internal or internal-external stimulus.

The concept of the Behavioural Man (Leśniewski, 2017, pp. 77-91; Papadopoulos, Shelly, Niyazi, \& Yang, 2006, pp. 403-418) is derived from behaviourism. Each organization generates various situations and conditions that contribute to specific employee behaviours. Situations and conditions affecting humans are external stimuli to which a person reacts in the form of a particular behaviour. Figure 1 shows the model of human behaviour.
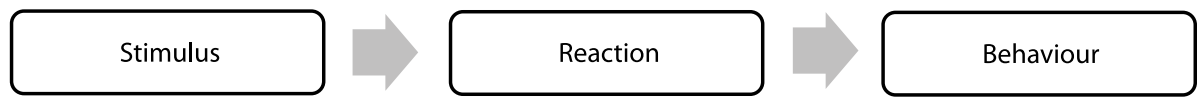

Legend:

Stimulus - something that makes a person act.

Reaction - a person gaining awareness of the situation they are currently in or can be in the future.

Behaviour - adoption of a specific procedure as a result of the previous reaction and stimulus (stimuli). It is also a kind of strategy that a person will accept. A behavioural strategy has its source in this interpretation.

Figure 1. The model of human behaviour. 
On the basis of the model in Figure 1, behaviour is the resultant component that shapes man. There must be a stimulus and reaction before a certain behaviour occurs. Each of these elements of the model contributes to the synergy of human functioning as a behavioural being.

Before proceeding to the full presentation of the concept of the Behavioural Man, two basic concepts should be distinguished: Man as a behavioural being and Behavioural Man. Man as a behavioural being is a person who reacts to a stimulus with a specific behaviour; while Behavioural Man is a man who creates situations and conditions that contribute to the behaviour of other people and draws conclusions for themselves from the behaviour of other people. It can be stated that every person is a behavioural being, because everyone behaves in their own way, but not every person is a behavioural person, because not everyone is able to create a situation or conditions that will modify the behaviour of other people.

In the concept of Behavioural Man, one can notice a strong interaction of one man with another, which can lead to manipulation of other people's behaviours (e.g. a strong personality affects a weaker personality). The manager realizing the management process has a specific effect on other people with the intention of achieving the goal. It should be remembered that in its essence human resources management is nothing but the influence of one man on another. Therefore, Behavioural Man is part of human resource management or organizational culture etc. Learning about the concept of Behavioural Man can contribute to more effective human resource management (Leśniewski, 2018a, pp. 79-98). Figure 2 shows the concept of Behavioural Man.

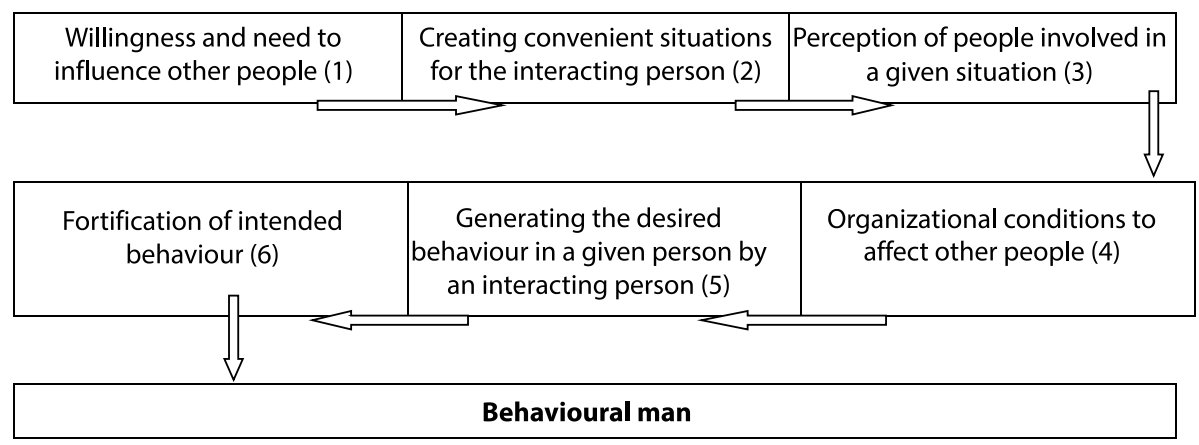

Figure 2. The concept of Behavioural Man.

Source: own based on Leśniewski, 2017, pp. 77-91.

The factors presented in Figure 2 are at the same time components and stages to complete to be a Behavioural Man. This concept begins with the desire and need (the need is understood internally as a psychological perceptible lack of someone, 
something and understood externally as a sociological perceptible lack of someone, something) to affect other people. Behavioural man creates situations that are convenient for him. People who are consciously influenced by the Behavioural Man are involved in these situations. However, Behavioural Man must take into account the fact that other persons from "outside the circle" may also be involved in these situations. For the development of Behavioural Man there must exist specific organizational conditions that will be favourable for him (e.g. Behavioural Man wants to promote his colleague at work and therefore creates such a situation/situations through which promotion is carried out, etc.).

The next step is to create the desired behaviour in a given person by an interacting person. Behavioural man achieves the behaviour that is satisfying for him. The last stage is the fortification of the intended behaviour in people who are in the centre of attention of the Behavioural Man.

The concept of Behavioural Man can be seen as a factual impact on other people with the intention of achieving the goal in an efficient and effective manner. This concept can also be seen as a way to manipulate other people. Whatever the point of view, this concept is part of the management of human resources or the problems of organizational culture and soft competitiveness. An in-depth analysis of the concept of Behavioural Man may be useful in further shaping the concept of Homo Oeconomicus or Homo Faber etc. Behavioural Man can be referred to a manager Behavioural Man as Manager and to a subordinate person - Behavioural Man as a Subordinate. Both of these people in the organization do not exclude each other. To the contrary, they complement each other.

\section{Man and competitiveness}

If man is presented as the beginning and end of the organization (enterprise) or as the initiator of all the activities in the organization, he can also be perceived as a source of competitiveness (Baran, 2015, pp. 5-182). The man's intellectual potential predisposes him to shape the competitiveness of the organization. Man (employee) occupying various positions and being at various levels of management participates indirectly and directly in the process of shaping competitiveness. Indirect participation in the process of shaping competitiveness occurs through executive employees, or subordinates. On the other hand, direct participation in the process of shaping competitiveness takes place through being a manager or managing staff. That is why it is very important for the organization to have quality managerial staff and quality executive employees (subordinates) (Leśniewski, 2016; 2017). It can be stated that the quality of employees is the quality of the organization. Due to the implementation of the management process by managers, they are ultimately responsible for shaping the competitiveness of the organization. The responsibility of managers for shaping 
competitiveness is one side of the coin. The other side of the coin is the predisposition to maintain and generate new competitiveness factors. One should be able to distinguish responsibility from predisposition because a manager by definition is to be responsible but not necessarily predisposed to shape competitiveness. Therefore, managers of the highest management level must, besides being responsible, have skills in the form of predisposition to shape competitiveness. Competitiveness (Man, Lau, \& Chan, 2002, pp. 123-142) of the whole organization rests in the hands of managers from the point of view of executing the management process. Competitive Man is a useful concept for managers when it comes to shaping competitiveness (Leśniewski, 2018b, pp. 123-135). This concept is based on the characteristics of the manager who knows how to generate and shape competitiveness factors and has creative inventiveness for such competitiveness factors, which the organization currently does not have, but which may contribute to the competitive advantage in the future. Competitive Man fully fits into the area of skills or competences which form one of the foundations (apart from thinking) to generate and then shape competitiveness factors ultimately contributing to a competitive advantage (Jedynak \& Budzanowska-Drzewiecka, 2017, pp. 5-130).

\section{Competitiveness of Behavioural Enterprises - conceptual model}

Competitiveness in general is a variety of factors or mix-elements that create it. Each competitiveness factor has a specific value ultimately contributing to the overall value of competitiveness. A specific relationship must exist between these factors so that they can be actively involved in the process of not only generating, but also shaping competitiveness. It should be remembered that generating competitiveness factors means their creation (building), while shaping competitiveness factors means profiling them so that they take a specific direction, e.g. direction - soft competitiveness, direction - hard competitiveness or direction - soft-hard competitiveness etc. Relations between competitiveness factors contribute to the behaviourality of these factors, which ultimately contributes to behavioural competitiveness. This competitiveness is understood as the behaviour of competitiveness factors caused by the relations between these factors. Behavioural competitiveness plays a fundamental role in: factor-dependent relations and factor-dependent behaviours. If there are no relationships between competitiveness factors (passive factors or in other words: dead factors), then there is no behaviour of these factors and thus there is no behavioural competitiveness. It is understandable that the organization cannot develop through passive competitiveness factors. Therefore, any organization that achieves a competitive advantage must have more or less developed behavioural competitiveness. Figure 3 presents a conceptual model of Behavioural Competitiveness of enterprises. 


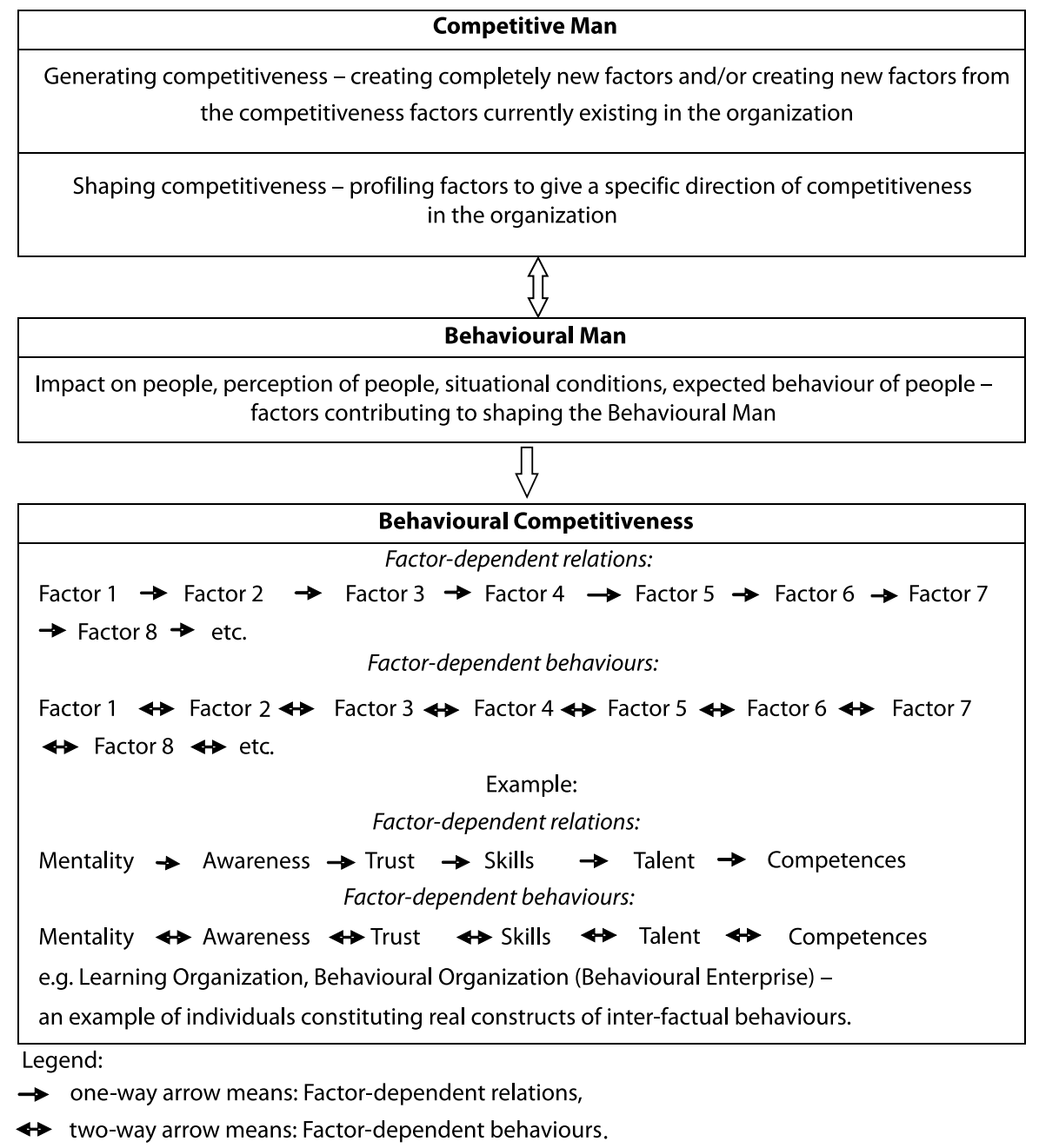

Figure 3. Conceptual model of Behavioural Competitiveness of enterprises.

Source: own study based on: Leśniewski, 2017, pp. 77-91; Leśniewski, 2018a, pp. 79-98; Leśniewski, 2018a, pp. 123-135.

The concept presented in the above figure is a different view of competitiveness seen through the prism of soft competitiveness. The starting point for creating Behavioural Competitiveness is Competitive Man and Behavioural Man. Both concepts of man face the problems associated with the development of the organization through the competitiveness and behaviour of the organization on the market. Behavioural competitiveness, in addition to these two concepts, strongly emphasizes the factor-dependent relations and factor-dependent behaviours. Factor-dependent 
relations are the relation (the occurrence of dependencies) between the factors of competitiveness, whereas factor-dependent behaviours mean the generation of specific results from factor-dependent relations. The relations correspond to, among others, the following questions: Are there links between competitiveness factors? Do Skills combine with Talent and Competences etc. Behaviours, however, answer the following questions: What is the result of the relationship between competitiveness factors? Can an organization with employees with developed Skills, Talent, Competences or Trust be a learning entity (learning organization) and/or a behavioural company etc.? In practice, enterprises should strive to intensify the relationship between competitiveness factors, which will ultimately contribute to specific results (behaviours) that are necessary for any organization wishing to participate in a market economy (Witczak, 2008, pp. 5-190).

An organization wishing to develop Behavioural Competitiveness must emphasize the creation of good, strong and, above all, quality relationships (Mitręga, 2005, pp. 5-147) which will contribute to the creation of specific solutions for a given organization.

\section{Conclusions}

Without man an organization cannot exist - let these words express the quintessence of thinking adopted in this study. Man is the foundation of the organization in each of its dimensions. Human activity aimed at the broadly understood development and growth is equipped with specific attributes, among others, in the form of the Behavioural Man and Competitive Man, which introduces the organization to the concept of behavioural competitiveness. This competitiveness can be otherwise defined as the competitiveness of behaviours. It should be remembered that competitiveness is not only the factors themselves, but also the factor-dependent behaviours that generate specific results needed for the development of the organization. Behaviour is needed to achieve the intended goal (result). Behavioural competitiveness is seen as an active side of factors that make a given organization (enterprises) competitive. The Behavioural Man and Competitive Man create relations and behaviours for factors that make the organization competitive.

Both of the concepts presented give importance to human being as the basic component of creating and shaping competitiveness, including the behavioural competitiveness of enterprises (competitiveness of behaviours). Man is the decision-maker when it comes to the direction of competitiveness and competitive advantage of the organization (enterprises). Both Behavioural Man and Competitive Man are an important complement to the existing human concepts, such as, Homo Oeconomicus, Homo Sociologicus, Homo Corporativus, Homo Humanistic Economicus, Homo Institutional Economicus, Homo Social Economicus, Homo 
Socio-Economicus or Homo Satisfaciendus (Tomer, 2001, pp. 281-293). Familiarity with the concept of man allows for not only understanding man but also gives the organization's development a specific direction, including the direction of competitiveness and competitive advantage.

The concept of the model of the behavioural competitiveness of enterprises emphasizes the importance and fundamentality of behaviour-oriented competitiveness.

The considerations presented in this article should contribute to further discussions on the importance of shaping competitiveness that allows for achieving and maintaining a competitive advantage. The author of this study hopes to improve the competitiveness of the enterprise which will implement the behavioural competitiveness model in the qualitative development of its organization.

\section{References}

Barnard, Ch. (1938). The Functions of the Executive. Cambridge, Mass: Harvard University Press.

Baran, M. (ed.) (2015). Poszukiwanie przewagi konkurencyjnej. Wybrane uwarunkowania. Kraków: Wydawnictwo Uniwersytetu Jagiellońskiego.

Budzanowska-Drzewiecka, M., Marcinkowski, A., \& Motyl-Adamczyk, A. (2016). Różnice kulturowe w komunikacji biznesowej. Kraków: Wydawnictwo Uniwersytetu Jagiellońskiego.

Crozier, M. (1993). Przedsiębiorstwo na podsłuchu. Jak uczyć się zarządzania postindustrialnego. Warszawa: Polskie Wydawnictwo Ekonomiczne.

Czakon, W. (2017). Tworzenie teorii w naukach o zarządzaniu. In A. Sopińska, P. Wachowiak (eds.), Wyzwania wspótczesnego zarządzania strategicznego. Warszawa: Oficyna Wydawnicza SGH.

Etzioni, A. (1964). Modern Organizations. Englewood Cliffs: Prentice Hall.

Hauswald, E. (1935). Organizacja i zarządzanie. Lwów: Wydawnictwo Gubrynowicz i Syn.

Jedynak, P. (ed.) (2010). Wiedza współczesnych organizacji. Wybrane problemy zarządzania, Kraków: Wydawnictwo Uniwersytetu Jagiellońskiego.

Jedynak, P., \& Budzanowska-Drzewiecka, M. (eds.) (2017). The Organizational Competitiveness: Approaches \& Challenges. Comprehensive Management Issues. Kraków: Jagiellonian University Press.

Juchnowicz, M. (2009). Kultura zaufania wyzwaniem współczesnego zarządzania kapitałem ludzkim. In M. Juchnowicz (ed.), Kulturowe uwarunkowania zarządzania kapitałem ludzkim. Kraków: Wolters Kluwer.

Juchnowicz, M. (2012). Zaangażowanie pracowników. Sposoby oceny i motywowania. Warszawa: Polskie Wydawnictwo Ekonomiczne.

Katz, D., \& Kahn, R.L. (1979). Społeczna psychologia organizacji. Warszawa: Państwowe Wydawnictwo Naukowe.

Kozina, A. (2014). Koncepcja dwuwymiarowej oceny kompetencji negocjacyjnych. Organizacja i Kierowanie, (3), 69-81.

Leśniewski, M.A. (2015). Konkurencyjność miękka przedsiębiorstw. Warszawa: Difin.

Leśniewski, M.A. (2016). The role of a manager in shaping behavioural cultural competitive advantage of the enterprises. Jagiellonian Journal of Management, 2(2), 115-134. 
Leśniewski, M.A. (2017). Behavioural-humanistic model of soft competitiveness of enterprises. Jagiellonian Journal of Management, 3(2), 77-91.

Leśniewski, M.A. (2018a). Pozytywny menedżer wiedzy decydentem stymulowania rozwoju zasobów przedsiębiorstwa. Akademia Zarządzania, 2(1), 79-98.

Leśniewski, M.A. (2018b). Człowiek Konkurencyjności - model koncepcyjny. In M. Budzanowska-Drzewiecka, K. Czernek (eds.), Kierunki ewolucji nauk o zarządzaniu. Kraków: Wydawnictwo Uniwersytetu Jagiellońskiego, pp. 123-135.

Man, T.W.Y., Lau, T., \& Chan, K.F. (2002). The competitiveness of small and medium enterprises: A conceptualization with focus on entrepreneurial competencies, Journal of Business Venturing, 17(2), 123-142.

Marek, N. (2011). Radykalny behawioryzm jako filozofia nauki. Semina Scientiarum, (10), 78-91.

Mitręga, M. (2005). Marketing relacji. Teoria i praktyka. Warszawa: CeDeWu, 5-147.

Oczkowska, R. (2014). Rozwój zasobów ludzkich - istota, instrumenty, podmioty. In R. Oczkowska, U. Bukowska (eds.), Rozwój zasobów ludzkich organizacji. Warszawa: Difin, pp. $5-182$.

Papadopoulos, N.T., Shelly, T.E., Niyazi, N., \& Jang, E. (2006). Olfactory and behavioral mechanisms underlying enhanced mating competitiveness following exposure to ginger root oil and orange oil in males of the mediterranean fruit fly, Journal of Insect Behavior, 19(3), 403-418.

Sułkowski, Ł., Rozkwitalska, M., \& Magala S. (eds.) (2017). Intercultural Interactions in the Multicultural Workplace. Traditional and Positive Organizational Scholarship, Springer.

Szulich, P. (2004). Wolność jako prawo przedsiębiorczości. In K. Jaremczuk (ed.), Uwarunkowania przedsiębiorczości. Tarnobrzeg: PWSZ im. S. Tarnowskiego w Tarnobrzegu, p. 36.

Szubaka, T. (2004). Behawioryzm. In J. Hartman, Słownik filozofii. Kraków: Zielona Sowa.

Tomer, J.F. (2001). Economic man vs. heterodox men: The concepts of human nature in schools of economic thought. The Journal of Socio-Economics, 30(4), 281-293.

Watson, J.B. (1990). Behawioryzm oraz psychologia, jak widzi ja behawiorysta. Warszawa: Wydawnictwo Naukowe PWN.

Witczak, O. (ed.) (2008). Budowanie związków z klientami na rynku business to business - teoria i praktyka. Warszawa: CeDeWu.

Wojtczuk-Turek, A. (2008). Kompetencje twórcze jako istotny składnik kapitału innowacyjnego przedsiębiorstw. In S.A. Witkowski, T. Listwan (eds.), Kompetencje a sukces zarządzania organizacją. Warszawa: Difin, pp. 471-483.

\section{Note about the Author}

Michą A. Leśniewski, Ph.D. - doctor of economic sciences in the field of management. He works at the Department of Management, the University of Jan Kochanowski in Kielce. His current research interests include soft management issues, soft competitiveness, cultural competitiveness, organizational culture and positive potential of organisations. He collaborates with such scientific journals as Ekonomika i Organizacja Przedsiębiorstwa and Przegląd Organizacji. He is the author of the monograph entitled Konkurencyjność miękka przedsiębiorstw [Soft Competitiveness of Enterprises] (2015). Warszawa: Difin. 